\title{
A prospective observational study on maternal near miss cases in a rural teaching hospital
}

\author{
Mamta Mahajan $^{1 *}$, Anjali Soni' ${ }^{1}$ C. D. Sharma1 ${ }^{1}$, Shelley Moudgil ${ }^{2}$
}

\begin{abstract}
${ }^{1}$ Department of Obstetrics and Gynaecology, Dr. Rajendra Prasad Government Medical College, Tanda Kangra, Himachal Pradesh, India

${ }^{2}$ Department of Obstetrics and Gynaecology, Ananta Institute of Medical Sciences and Research Centre, Rajasamand Rajasthan, India
\end{abstract}

Received: 28 August 2021

Revised: 19 October 2021

Accepted: 20 October 2021

\section{*Correspondence: \\ Dr. Mamta Mahajan, \\ E-mail: drmamtamahajan@gmail.com}

Copyright: () the author(s), publisher and licensee Medip Academy. This is an open-access article distributed under the terms of the Creative Commons Attribution Non-Commercial License, which permits unrestricted non-commercial use, distribution, and reproduction in any medium, provided the original work is properly cited.

\begin{abstract}
Background: Women who have survived complications during pregnancy and child birth have been studied and termed Maternal near miss (MNM). All near misses should be interpreted as free lesson and opportunities to improve the quality of service provision. The aim of the study was to know the incidence, risk factors and underline causes of MNM in our setup as there is limited data from Himachal Pradesh.

Methods: The present study was a prospective observational study that was carried out in the department of Obstetrics and Gynecology, Dr. Rajendra Prasad Government Medical College Kangra at Tanda (HP), from 1st January 2018 to 31st December 2018. The patients in this study were, pregnant women who nearly died but survived a complication that occurred during pregnancy, child birth or within 42 days of termination of pregnancy as per WHO MNM criteria 2009. Results: A total of 9690 live births, 5 maternal deaths and 116 MNM cases were reported during the study period. Incidence of MNM observed was 12\%. Hypertensive disorders of pregnancy 39.6\% cases were most common cause for MNM followed by obstetric hemorrhage $31.03 \%$ cases. Majority of neonates i.e.; $58 \%$ were admitted to NICU and only $52.7 \%$ survived the postnatal complications.

Conclusions: Critical analysis of MNM cases will help us in identifying the deficiencies in obstetric care. Maternal mortality and morbidity can be reduced if timely and effective care can be given to women experiencing acute pregnancy related complications. There is need for validation of 'MNM' criteria at peripheral levels which will enable them in early identification and timely referral of such cases to tertiary centers.
\end{abstract}

Keywords: Maternal near miss, Maternal mortality, Mortality index

\section{INTRODUCTION}

Each year in India, roughly 28 million women experience pregnancy and 26 million have live births, of these an estimated 67000 maternal deaths occur every year. ${ }^{1}$ Maternal mortality is one of the most important indicators used for the overall development of a nation. India has committed itself to achieve Sustainable development goals (SDGP) over the next 15 years. SDG goal 3A targets to reduce the global Maternal mortality ratio (MMR) to less than 70 per 100,000 live births by $2030 .^{2}$

MMR in India has steadily declined over the years but it is still almost double SDGP. It is estimated that every woman who dies 20 or more survive severe maternal complications as a result of the pregnancy or delivery. ${ }^{3}$ Investigating these women will increase the understanding of failures in obstetrical care within the health care system. In 2009, WHO introduced the concept of 'maternal near- 
miss (MNM)' for evaluating the quality of care for severe pregnancy complications. ${ }^{4} \mathrm{~A}$ woman who survives lifethreatening conditions during pregnancy, abortion, and childbirth or within 42 days of pregnancy termination, irrespective of receiving emergency medical/surgical intervention, is called MNM. ${ }^{5}$

The WHO the near-miss approach was published in 2011 to serve as a manual for conducting MNM studies. ${ }^{5}$ The manual provides guidelines to implement MNM studies, calculations of MNM indicators, a data collection tool as well as guidance for interpretation.

As MNM cases occur much more frequently than maternal deaths, there has been increasing interest internationally in studying these cases. The maternal death review system has been institutionalized in India. Once we unfold the reasons for near-miss cases, we can take effective measures to avoid these eventualities. MNM guidelines will be useful to the states in identifying the required action needed for improving both maternal and neonatal health.

The aim of the study was to recognize these women and review the common pathways leading to severe morbidity. A review of these cases has the potential to highlight the deficiencies, as well as the positive elements in the provision of obstetric services in our health system.

\section{Aim and objectives}

The aim and objective of the study were (a) to study the incidence of MNM cases and to identify the causes responsible for the MNM cases; and (b) to study maternal and fetal outcomes in MNM cases.

\section{METHODS}

The present study was a prospective observational study that was carried out in the department of Obstetrics and Gynecology, Dr. Rajendra Prasad Government Medical College Kangra at Tanda (HP), from $1^{\text {st }}$ January 2018 to $31^{\text {st }}$ December 2018 after taking approval from the institutional ethics committee.

\section{Study population}

The patients in the study were pregnant women who nearly died but survived a complication that occurred during pregnancy, childbirth, or within 42 days of termination of pregnancy as per WHO MNM criteria. Inclusion criteria as per WHO Near Miss Approach for maternal health (Table 1). These women were prospectively followed during or within 42 days of termination of pregnancy (including abortion) and maternal and fetal outcomes were assessed accordingly.

\section{Exclusion criteria}

MNM or maternal death occurring after 42 days of termination of pregnancy. MNM or maternal death occurring because of accidental or incidental causes. Patient characteristics including age, parity, gestational age at admission, booked or unbooked and referred and sociodemographic profiles were considered. Maternal outcomes observed were; ICU admission, mode of delivery, or other surgical intervention to save life of mother and whether blood transfusion was needed or not. Fetal outcomes studied were; live birth/stillbirth, preterm/term, NICU admissions, and neonatal deaths.

\section{Statistical analysis}

Data was presented as frequency and percentage.

\section{RESULTS}

A total of 9690 live births, 5 maternal deaths were reported and 116 women satisfied WHO MNM inclusion criteria and were included in the study.

Incidence of MNM observed was 12\% (number of MNM cases divided by the total number of live births). Mortality index (MI): Number of maternal deaths divided by the number of women with life-threatening conditions expressed as a percentage. A low index suggests better quality of health care. (MI=MD/MNM+MD)100 In the present study MI was $4.1 \%$. Table 1 shows the characteristics of women with a near miss.

Majority of MNM cases were between 21-25 years $(33.6 \%)$ and the least number of cases were reported in the age group less than 20 years. The mean age of MNM cases was $27.82 \pm 5.65$ years. The majority of MNM cases $(47.4 \%)$ were referred from peripheral health centers. Our hospital caters to all high-risk pregnancies referred from other adjoining districts like Chamba, Una, Hamirpur and few areas from Mandi. Large catering area and unavailability of a tertiary care center is the major cause of such a high incidence of referrals. The majority of the cases $(65.5 \%)$ did not receive any treatment before reaching our institution (Figure 1). Most of the patients were from rural backgrounds $(67.4 \%)$. The majority of MNM cases $57.8 \%$ were multiparous while $42.2 \%$ cases were primigravida. A maximum number of pregnant women $(55.2 \%)$ were at a period of gestation $29-40$ weeks at the time of complication (Table 2).

Hypertensive disorders of pregnancy $(39.6 \%)$ were the most common cause for MNM cases closely followed by obstetric hemorrhage $(31.03 \%)$ in $14.6 \%$ of pregnant women ruptured ectopic pregnancy was the cause for MNM, incomplete abortion in $4.3 \%$ while sepsis was reported in $6.9 \%$ cases (Table 3 ).

Only $30.2 \%$ of the women required ICU admission (Figure 2). More than half of the pregnant women (56.9\%) had a blood transfusion ( $>5$ units of blood or blood products Figure 3). 
Table 4 shows pregnancy outcome of MNM cases. There were $37.9 \%$ MNM cases who delivered vaginally, LSCS in $23.3 \%$ cases followed by exploratory laparotomy for ruptured ectopic in $14.7 \%$ cases. Out of $116 \mathrm{MNM}$ cases, $8(6.9 \%)$ women had peripartum hysterectomies for different indications like atonic $\mathrm{PPH}$, placenta accreta, and ruptured uterus. Table 5 shows neonatal outcome of MNM cases. There was a total of $53.4 \%$ live births and the majority of the neonates i.e., $58 \%$ were admitted to NICU in view of prematurity and low Apgar score at 1 and 5 minutes of birth. Only $52.7 \%$ of the neonates survived the postnatal complications.

Table 1: Inclusion criteria- the WHO near-miss approach for maternal health.

\begin{tabular}{|c|c|}
\hline \multicolumn{2}{|l|}{ Inclusion criterias } \\
\hline Severe maternal complications & $\begin{array}{l}\text { - Severe postpartum haemorrhage } \\
\text { - } \quad \text { Severe pre-eclampsia } \\
\text { - } \quad \text { Eclampsia } \\
\text { - } \quad \text { Sepsis or severe systemic infection } \\
\text { - } \quad \text { Ruptured uterus } \\
\text { Severe complications of abortion }\end{array}$ \\
\hline $\begin{array}{l}\text { Critical interventions or intensive } \\
\text { care unit use }\end{array}$ & $\begin{array}{l}\text { - } \\
\text { - } \\
\text { - } \\
\text { - }\end{array}$ \\
\hline $\begin{array}{l}\text { Life-threatening conditions (near- } \\
\text { miss criteria) } \\
\text { Cardiovascular dysfunction }\end{array}$ & $\begin{array}{l}\text { - } \text { Shock } \\
\text { - } \quad \text { Cardiac arrest (absence of pulse/heart beat and loss of consciousness), } \\
\text { - } \quad \text { Use of continuous vasoactive drugs } \\
\text { - } \quad \text { Severe hypoperfusion }(\text { lactate }>5 \mathrm{mmol} / \mathrm{l} \text { or }>45 \mathrm{mg} / \mathrm{dl}) \\
\text { - } \quad \text { Severe acidosis }(\mathrm{pH}<7.1)\end{array}$ \\
\hline Respiratory dysfunction & $\begin{array}{l}\text { - } \text { Acute cyanosis } \\
\text { - } \text { Gasping, } \\
\text { - } \quad \text { Severe tachypnea (respiratory rate }>40 \text { breaths per minute), } \\
\text { - } \quad \text { Severe bradypnea (respiratory rate }<200 \text { ) } \\
\text { - } \quad \text { Intubation and ventilation not related to anaesthesia, } \\
\text { - } \quad \text { Severe hypoxemia }\left(\mathrm{O}_{2} \text { saturation }<90 \% \text { for } \geq 60 \text { min or } \mathrm{PAO}_{2} / \mathrm{FiO}_{2}<200\right)\end{array}$ \\
\hline Renal dysfunction & $\begin{array}{l}\text { - Oliguria non-responsive to fluids or diuretics, } \\
\text { - } \quad \text { Dialysis for acute renal failure, } \\
\text { - } \text { Severe acute azotemia (creatinine } \geq 300 \mu \mathrm{mol} / \mathrm{ml} \text { or } \geq 3.5 \mathrm{mg} / \mathrm{dl} \text { ) }\end{array}$ \\
\hline $\begin{array}{l}\text { Coagulation/haematological } \\
\text { dysfunction }\end{array}$ & $\begin{array}{l}\text { - } \quad \text { Failure to form clots, } \\
\text { - } \quad \text { Massive transfusion of blood or red cells ( } \geq 5 \text { units }) \text {, } \\
\text { - } \quad \text { Severe acute thrombocytopenia }(<50000 \text { platelets per } \mathrm{ml})\end{array}$ \\
\hline Hepatic dysfunction & $\begin{array}{l}\text { - Jaundice in the presence of pre-eclampsia } \\
\text { - Severe acute hyperbilirubinemia (bilirubin }>100 \mu \mathrm{mol} / \mathrm{l} \text { or }>6.0 \mathrm{mg} / \mathrm{dl} \text { ) }\end{array}$ \\
\hline Neurological dysfunction & $\begin{array}{l}\text { - } \quad \text { Prolonged unconsciousness (lasting } \geq 12 \text { hours) } \\
\text { - Coma (including metabolic coma), stroke, uncontrollable fits/status } \\
\text { epilepticus } \\
\text { - } \quad \text { Total paralysis }\end{array}$ \\
\hline Uterine dysfunction & - Uterine haemorrhage or infection leading to hysterectomy \\
\hline
\end{tabular}

Table 2: Maternal characteristics.

\begin{tabular}{|c|c|c|}
\hline Characteristics & $\mathrm{N}=116$ & $\%$ \\
\hline Mean maternal age in years & $27.82 \pm 5.65$ & \\
\hline \multicolumn{3}{|l|}{ Antenatal supervision } \\
\hline Referred & 55 & 47.1 \\
\hline Booked & 38 & 32.8 \\
\hline Unbooked & 23 & 19.8 \\
\hline \multicolumn{3}{|l|}{ Socio-demographic profile } \\
\hline Rural & 75 & 64.7 \\
\hline Urban & 41 & 35.3 \\
\hline \multicolumn{3}{|l|}{ Parity } \\
\hline Primigravida & 49 & 42.2 \\
\hline
\end{tabular}




\begin{tabular}{|lll|}
\hline Characteristics & $\mathbf{N = 1 1 6}$ & $\%$ \\
\hline Multigravida & 67 & 57.8 \\
\hline Gestational age (weeks) & & 15.5 \\
\hline$\leq 12$ & 18 & 15.5 \\
\hline $13-28$ & 18 & 55.2 \\
\hline $29-40$ & 64 & 13.8 \\
\hline Postpartum period & 16 & \\
\hline
\end{tabular}

Table 3: Underline cause of near miss cases $(\mathrm{N}=116)$.

\begin{tabular}{|c|c|c|}
\hline Underline cause & $\mathbf{N}$ & $\%$ \\
\hline Hypertensive disorders & 46 & 39.7 \\
\hline Obstetric hemorrhage & 36 & 31.0 \\
\hline Ectopic pregnancy & 17 & 14.7 \\
\hline Sepsis & 8 & 6.9 \\
\hline Incomplete abortion & 5 & 4.3 \\
\hline Medical/surgical complications & 4 & 3.4 \\
\hline
\end{tabular}

Table 4: Pregnancy outcome of near miss cases $(\mathrm{N}=116)$.

\begin{tabular}{|c|c|c|c|c|c|c|c|c|c|}
\hline \multirow[t]{2}{*}{$\begin{array}{l}\text { Suction } \\
\text { evacua- } \\
\text { tion }\end{array}$} & \multicolumn{2}{|c|}{$\begin{array}{l}\text { Vaginal delivery } \\
\mathrm{N}=54(\mathbf{4 6 . 5 5 \%})\end{array}$} & \multirow[t]{2}{*}{ LSCS } & \multicolumn{2}{|c|}{$\begin{array}{l}\text { Laprotomy } \\
\mathrm{N}=19(\mathbf{1 6 . 3 8 \%})\end{array}$} & \multicolumn{3}{|c|}{$\begin{array}{l}\text { Peripartum hysterectomy } \\
\mathrm{N}=\mathbf{8}(6.9 \%)\end{array}$} & \multirow[t]{2}{*}{$\begin{array}{l}\text { Hyster- } \\
\text { otemy }\end{array}$} \\
\hline & $\begin{array}{l}\text { Normal } \\
\text { delivery }\end{array}$ & Instrumental & & $\begin{array}{l}\text { Rupture } \\
\text { uterus }\end{array}$ & $\begin{array}{l}\text { Ectopic } \\
\text { pregnancy }\end{array}$ & $\begin{array}{l}\text { Atonic } \\
\text { PPH }\end{array}$ & $\begin{array}{l}\text { Placenta } \\
\text { acreta }\end{array}$ & $\begin{array}{l}\text { Rupture } \\
\text { uterus }\end{array}$ & \\
\hline $\begin{array}{l}5 \\
(4.3 \%)\end{array}$ & $\begin{array}{l}44 \\
(37.9 \%)\end{array}$ & $\begin{array}{l}10 \\
(8.6 \%)\end{array}$ & $\begin{array}{l}27 \\
(23.3 \%)\end{array}$ & $2(1.7 \%)$ & $\begin{array}{l}17 \\
(14.7 \%)\end{array}$ & $\begin{array}{l}3 \\
(2.59 \%)\end{array}$ & $\begin{array}{l}4 \\
(3.45 \%)\end{array}$ & $\begin{array}{l}1 \\
(0.86 \%)\end{array}$ & $\begin{array}{l}3 \\
(2.6 \%)\end{array}$ \\
\hline
\end{tabular}

Table 5: Neonatal outcome.

\begin{tabular}{|c|c|c|c|c|c|c|c|c|}
\hline \multicolumn{9}{|c|}{ Outcome* } \\
\hline \multicolumn{2}{|c|}{ Gestation N=94 } & \multicolumn{2}{|c|}{ Stillbirth N=32 } & \multirow{3}{*}{$\begin{array}{l}\text { Livebirth } \\
\text { N (\%) }\end{array}$} & \multicolumn{4}{|c|}{ NICU Admission N=36 (58.06\%) } \\
\hline \multirow{2}{*}{$\begin{array}{l}\text { Preterm } \\
\text { N }(\%)\end{array}$} & \multirow{2}{*}{$\begin{array}{l}\text { Term } \\
\mathrm{N}(\%)\end{array}$} & \multirow{2}{*}{$\begin{array}{l}\text { Fresh N } \\
(\%)\end{array}$} & \multirow{2}{*}{$\begin{array}{l}\text { Macerated } \\
\mathrm{N}(\%)\end{array}$} & & \multicolumn{2}{|l|}{ Indication } & \multicolumn{2}{|l|}{ Outcome } \\
\hline & & & & & $\begin{array}{l}\text { Prematurity } \\
\mathrm{N}(\%)\end{array}$ & $\begin{array}{l}\text { Low Apgar score } \\
\mathrm{N}(\%)\end{array}$ & $\begin{array}{l}\text { Discharged } \\
N(\%)\end{array}$ & $\begin{array}{l}\text { Died } \\
N(\%)\end{array}$ \\
\hline $52(55.3)$ & $\begin{array}{l}42 \\
(44.7)\end{array}$ & $\begin{array}{l}12 \\
(12.77)\end{array}$ & $\begin{array}{l}20 \\
(21.3)\end{array}$ & $\begin{array}{l}62 \\
(65.96)\end{array}$ & $\begin{array}{l}20 \\
(55.56)\end{array}$ & $\begin{array}{l}16 \\
(44.44)\end{array}$ & $\begin{array}{l}19 \\
(52.7)\end{array}$ & $\begin{array}{l}17 \\
(47.2)\end{array}$ \\
\hline
\end{tabular}

Note: *Outcome of 94 cases (excluding ectopic pregnancy and incomplete abortion cases)

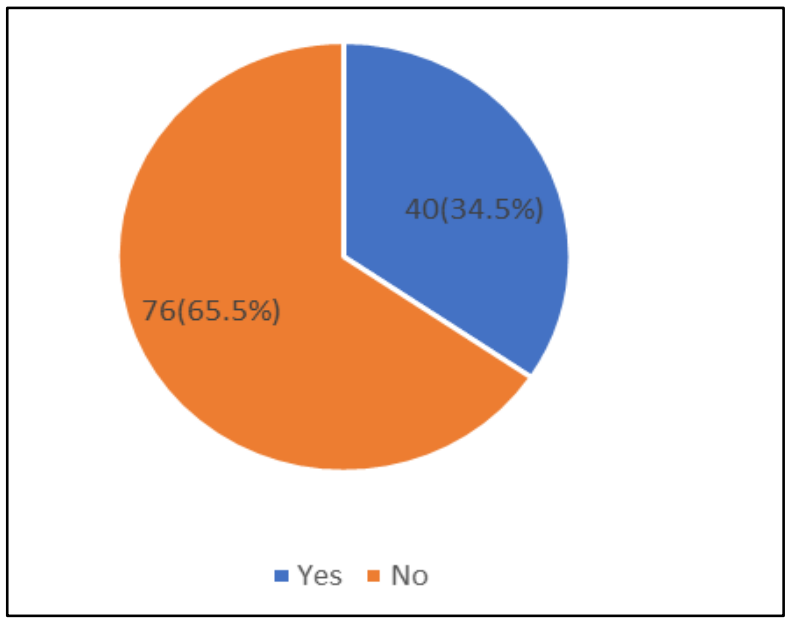

Figure 1: Distribution of patients according to treatment received before admission.

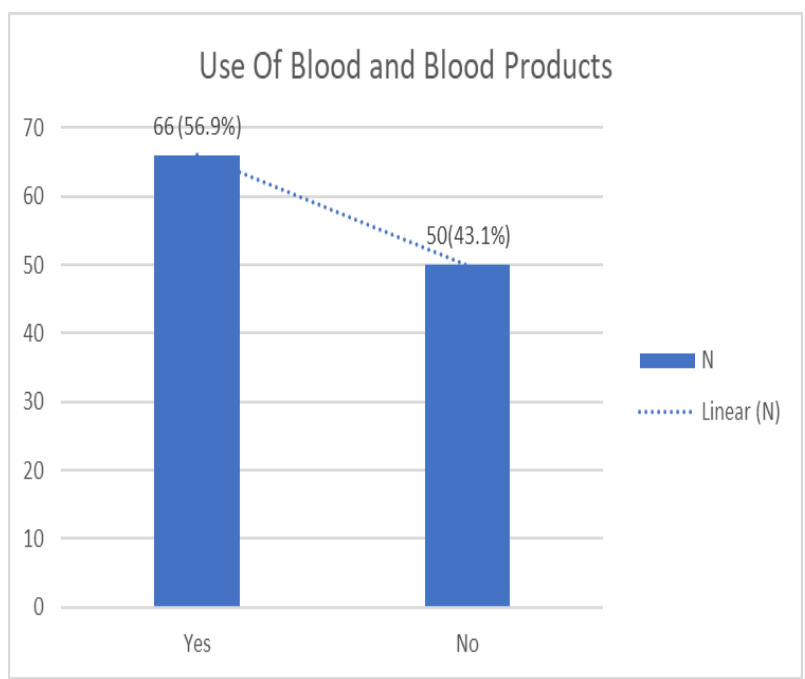

Figure 2: Distribution of patients according to use of blood and blood products. 


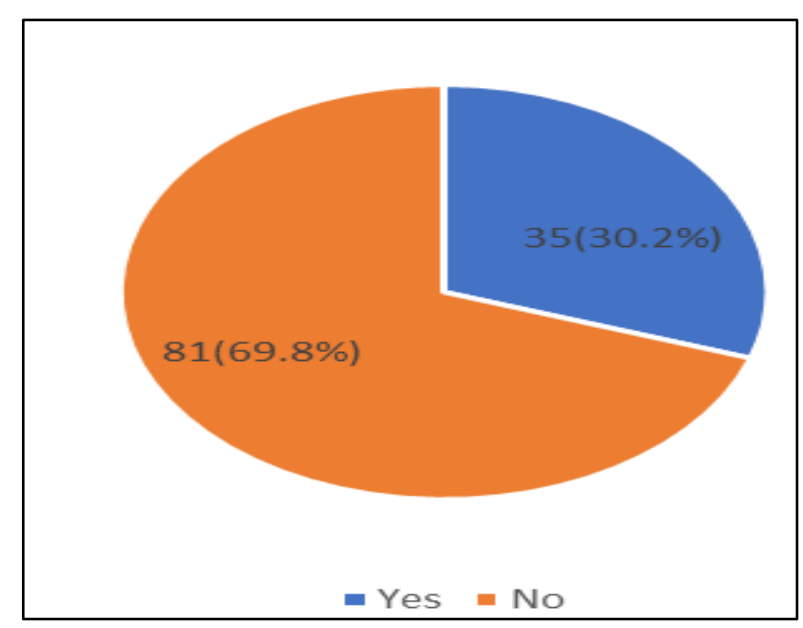

Figure 3: Distribution of patients according to ICU admission.

\section{DISCUSSION}

Maternal mortality is a critical indicator to assess the quality of services provided by a health care system. Globally, there has been a decline in MMR. There is a need to further accelerate this decline. This study was done to know the incidence, risk factors, and underline causes of MNM in our setup as there is limited published data from Himachal Pradesh.

In the present study, the incidence of MNM was found to be $12 \%$ which was similar to $11.6 \%$ as obtained by Yelikar et al in a tertiary care center in Maharashtra. ${ }^{6}$ The reported incidence varies from $5.1 \%$ to $40 \%$ in other studies from all over India., ${ }^{4,7}$ In our study we have 22 MNM for 1 maternal death, though it is appreciable with so much overload of deliveries still we need to improve to achieve national goals and targets.

The mean age of MNM cases was 27.82 \pm 5.65 years and the majority of cases $64.7 \%$ were from rural areas, these observations were comparable to the study conducted by Kaur et al tertiary care hospital at Shimla, the mean age of MNM cases was 26.62 \pm 5.63 years and majority $79 \%$ MNM cases belonged to rural areas. ${ }^{8}$

In the present study, $57.8 \%$ of patients were multigravida and $42.2 \%$ were primigravida which was comparable to a study conducted by Kaur et al in a tertiary care hospital Punjab. ${ }^{9}$ Out of 116 MNM cases, majority of cases i.e.; 64 $(55.4 \%)$ were reported in the third trimester, similar findings were found in the study done by Bakshi et al and Roopa et al where $52.5 \%$ and $57.2 \%$ MNM cases respectively, reported in the third trimester. ${ }^{7,10}$ Early age at marriage and conception, inappropriate antenatal care during pregnancy and late identification and late intervention of high-risk pregnancies are important contributors to MNM cases.

Hypertensive disorder (39.6\%) was the underlying cause of $\mathrm{MNM}$ in the majority of women, a similar observation was made in other studies. ${ }^{6,11,12}$ While Taly et al, Roost et al and Manandhar et al reported hemorrhage 60\%,48\%, and $41.66 \%$ as the most common cause of MNM respectively. ${ }^{13-15}$ Though there is rampant use of drugs like labetalol, magnesium sulphate to control pre-eclampsia and eclampsia at peripheral health centers, we still need to work on prediction and prevention of hypertensive disorders in pregnancy. In the present study, sepsis was identified as a cause of maternal near-miss events in $6.9 \%$ of the cases, which is a good indicator of improvements in clean delivery practices in our state. Under a beneficiary scheme called "Janani Shishu Suraksha Karyakaram" which provides free of cost treatment and hospitalization, antibiotics are freely available in the hospital supply leading to a lowering of the sepsis rate. In present study out of 116 women 35 (30.2\%) were admitted to ICU and most common indication being eclampsia and others being antepartum hemorrhage, PIH with heart disease, RHD (rheumatic heart disease), and chorioamnionitis.

Sixty-six $(56.9 \%)$ women required $>5$ units of blood and blood products which were comparable with the study conducted by Kalra et al where $58.9 \%$ of MNM cases had a blood transfusion. ${ }^{16}$ Twenty-four-hour blood bank facilities with availability of blood components are present at our institution, whereas most of private and government hospitals in the periphery lack blood bank facilities and making this the most common cause for referral. Anemia without hemorrhage was also an important indirect cause of MNM. Severe anemia is a major problem in India that needs to be addressed in order to reduce the incidence of a maternal near miss. The minor a procedure like suction and evacuation can be life-saving for women with incomplete abortion if timely done at peripheral health institution but due to strict PC PNDT act, lack of skill and manpower it is not done. Non-availability of blood bank and late reporting of these women to tertiary care center is an important cause of MNM.

There were $65.96 \%$ live births and $34.07 \%$ stillbirths which were comparable with the study conducted by Parmar et al where the total live birth rate was $61 \%$ and stillbirth was $39.2 \% .{ }^{4}$ Underline causes of MNM cases like a hypertensive disorder of pregnancy, APH may be the reason for the high stillbirth rate. There were more admissions to NICU i.e.; $58.06 \%$, in contrast, to study conducted by Kaur et al where NICU admission was $43.3 \% .^{8}$ High perinatal morbidity and mortality was attributed to un-booked cases, preterm births, and hypoxic insult due to pre-eclampsia and eclampsia.

\section{Limitation}

The limitation of this study was short term study duration.

\section{CONCLUSION}

India has made significant progress in reducing its maternal mortality rate and a lot more needs to be done. Through the present study, we have tried to understand the 
causes responsible for maternal morbidity. A study of MNM and its associated factors has helped us to identify what important steps were not taken correctly before referral which has impacted survival high-risk cases. As the main cause of MNM in the present study were hypertensive disorders of pregnancy so management protocols should be strictly followed for hypertensive disorders. Obstetric units should practice drills on the management of life-threatening conditions regularly so that prompt action can be taken in time of need. All maternal near-miss cases are living lessons who in spite of their misery show us our deficiencies and thereby help us in advocacy with referral facility to develop a Standard operating protocol (SOP) for management of high-risk cases at peripheral health institutes before referral.

Funding: No funding sources

Conflict of interest: None declared

Ethical approval: The study was approved by the Institutional Ethics Committee

\section{REFERENCES}

1. National Health Mission. Home, 2019. Available at: https://mohfw.nic.in/maternalhealth.htmp. Accessed on 20 August 2021.

2. UN. 2. Sustainable development goals:17 goals to transform our world, 2019. A https://www.un.org/sustevelopment/health. Accessed on 20 August 2021.

3. Chikadaya H, Madziyire MG, Munjanja SP. Incidence of maternal near miss in the public health sector of Harare, Zimbabwe: a prospective descriptive study. BMC Pregnancy Childbirth. 2018;18(1):458.

4. Parmar N, Parmar A, Mazumdar VS. What can we miss in identifying 'maternal near miss' event? IJCRR. 2014;6:45-50.

5. WHO. Evaluating the quality of care for severe pregnancy complications. The WHO near miss approach for maternal health, 2019. Available at: https://www.who.int/reproductivehealth/publications/ monitoring/9789241502221/en. Accessed on 20 August 2021.

6. Yelikar KA, Deshpande SS, Deshmukh SF. Severe Acute Maternal Morbidity in a Tertiary Care Center with Basic Intermediate Respiratory Care Units Setup. Int J Sci Stud. 2015;3:36-40.

7. Bakshi RK, Aggarwal P, Roy D, Nautial R. Indicators of maternal "near miss" morbidity at different levels of health care in North India: A pilot study. Bangladesh J Med Sci. 2015;14:254-57.

8. Kaur S, Minhas S, Sharma BR, Sood R. Maternal near miss and maternal mortality as health indicators in a tertiary care hospital. J Evolut Med Dent Sci. 2014;3:10354-62.

9. Kaur K, Garg S, Walia SS. A one year audit of maternal near miss and maternal death at tertiary care hospital. JMCSR. 2018;6:705-10.

10. Verma S, Rai L, Kumar P, Pai MV, Shetty J. "Near miss" obstetric events and maternal deaths in a tertiary care hospital: an audit. J Pregnancy. 2013;2013:393758.

11. Patanakar A, Uikey P, Rawlani N. Severe Acute Maternal Morbidity (Near Miss) in a Tertiary Care Center in Maharashtra: A Prospective Study. Int J Sci Stud. 2016;4:134-40.

12. Samant PY, Dhanawat J. Maternal near miss: an Indian tertiary care center audit. Int $\mathbf{J}$ Reprod Contracept Obstet Gynecol. 2019;8:1874-9.

13. Taly A, Gupta S, Jain N. Maternal intensive care and 'Near-miss'. Mortality in obstetrics. J Obstet Gynecol India. 2004;54:478-82.

14. Roost M, Altamirano V, Liljestrand J, Essen B. Priorities in emergency obstetrics care in Boliviamaternal mortality and near miss morbidity in metropolitan La Paz. BJOG. 2019;116:1210-17.

15. Manandhar SR, Manandhar D, Adhikari D, Shreshta J, Rai C, Rana H, et al. Analysis of obstetrics near miss cases of different health facilities of electoral constituency 2 of Arghakhanchi district. Nepal J Obstet Gynecol. 2014;18:38-41.

16. Kalra P, Kachhwaha CP. Obstetrics near miss morbidity and maternal mortality in a Tertiary care center in Western Rajasthan. Indian J Public Health. 2014;58:199-201.

Cite this article as: Mahajan M, Soni A, Sharma $\mathrm{CD}$, Moudgil S. A prospective observational study on maternal near miss cases in a rural teaching hospital. Int J Reprod Contracept Obstet Gynecol 2021;10:4448-53. 